\title{
Neutrophil Adherence Induced by Lipopolysaccharide In Vitro Role of Plasma Component Interaction with Lipopolysaccharide
}

\author{
G. Scott Worthen, ${ }^{*}$ Natalie Avdi, ${ }^{*}$ Stanley Vukajlovich, ${ }^{\star}$ and Peter S. Tobias ${ }^{*}$ \\ * Departments of Medicine, National Jewish Center for Immunology and Respiratory Medicine and University of Colorado School of \\ Medicine, Denver, Colorado 80206; ${ }^{\ddagger}$ Department of Microbiology, University of Kansas School of Medicine, Kansas City, Kansas 66103; \\ ${ }^{\S}$ Department of Immunology, Scripps Clinic and Research Foundation, La Jolla, California 92037
}

\begin{abstract}
Endotoxemia results in neutrophil localization within a number of microcirculatory beds, reflecting in part an adhesive interaction between neutrophils and the vascular endothelial cell. In previous studies, endotoxin or lipopolysaccharide (LPS) treatment of rabbits resulted in neutrophil sequestration at LPS concentrations well below those effective at increasing neutrophil adherence in vitro. We hypothesized that LPS-induced neutrophil adherence involved a plasma component. In the absence of plasma, high concentrations of LPS $(10 \mu \mathrm{g} / \mathrm{ml})$ were required to increase human neutrophil adherence to endothelial cells in vitro. With the inclusion of as little as $1 \%$ plasma or serum, however, the LPS dose-response curve was markedly shifted, resulting in increments in adherence at $10 \mathrm{ng} / \mathrm{ml}$, and the time course of enhanced adherence was accelerated. Pretreatment studies suggested that the effect of LPS was on the neutrophil rather than the endothelial cell. Immunoprecipitation of 0111:B4 LPS paralleled the loss of functional activity, suggesting that LPS was an integral part of the active complex, rather than altering a plasma component to make it active. The incubation of plasma with LPS decreased the apparent molecular mass of LPS from 500-1,000 kD to $\sim 100 \mathrm{kD}$. The disaggregated 0111:B4 LPS eluted in the range of albumin and was able to increase adherence in the absence of additional plasma. Plasma depleted of lipoproteins or heat treated retained activity, suggesting that the interaction of LPS with HDL or complement did not account for the observed findings. An LPSbinding protein isolated from rabbit serum enhanced the adherence-inducing effects of both 0111:B4 and Re595 LPS. Furthermore, the activity of rabbit serum was abolished after incubation with an antibody directed against this LPS-binding protein (LBP). An antibody directed against CD14, the putative receptor of the LPS-LBP complex, prevented the adhesive response to LPS. These data suggest that LPS is disaggregated by an LBP in serum and plasma to form an active LPS-plasma component complex. This putative complex then interacts with CD14 on the neutrophil so as to induce an adhesive state. ( $J$.
\end{abstract}

Address reprint requests to Dr. Worthen, Department of Medicine, National Jewish Center for Immunology and Respiratory Medicine, 1400 Jackson Street, Denver, CO 80206.

Received for publication 17 July 1991 and in revised form 19 May 1992.

J. Clin. Invest.

(c) The American Society for Clinical Investigation, Inc.

$0021-9738 / 92 / 12 / 2526 / 10 \quad \$ 2.00$

Volume 90, December 1992, 2526-2535
Clin. Invest. 1992.90:2526-2535.) Key words: CD14 receptor• endothelial cells $\bullet$ lipopolysaccharide binding protein

\section{Introduction}

Endotoxemia has been linked to a variety of catastrophic disorders, including acute lung injury $(1,2)$, renal failure $(3)$, disseminated intravascular coagulation (4), and circulatory collapse (5). Studies of the mechanisms by which bacterial endotoxins produce such severe reactions suggest that the biologically active lipopolysaccharide (LPS) portion of endotoxin interacts with a variety of humoral and cellular mediators (6). The neutrophil may play an important role in endotoxin-related syndromes $(4,5,7)$, but the mechanisms by which LPS enhances the injurious potential of neutrophils remains uncertain. The adherence of neutrophils to vascular endothelium is a critical prelude to neutrophil-mediated injury (8), and neutrophil sequestration in vascular beds in response to minute quantities of LPS has been recognized for decades (9). Whether this effect represents a direct effect on the neutrophil (10) or the endothelial cell (11), or an indirect effect mediated through yet another mediator pathway (12) remains uncertain. Each has been proposed.

We demonstrated that ex vivo pretreatment of neutrophils with nanogram per milliliter concentrations of LPS in the presence of plasma enhanced neutrophil sequestration in the lung without requiring complement (13). Dahinden et al. (10) similarly demonstrated the ability of low concentrations of LPS to induce human neutrophil adherence to plastic in the presence of plasma. These data contrast sharply with studies in which microgram per milliliter concentrations of LPS were required to exert effects in the absence of plasma (14).

Accordingly, we sought to determine the effect of plasma and serum on LPS induction of neutrophil adhesion to endothelial cells. We hypothesized that the presence of plasma would facilitate LPS-induced neutrophil adhesiveness by complement-independent mechanisms. Our data suggest that LPSinduced neutrophil adhesion to endothelial cells is enhanced by plasma under circumstances in which LPS appears to be disaggregated. The effect of LPS in the presence of plasma is exerted primarily on the neutrophil during the short $(<60$ min) time periods examined here. An LPS-binding protein (LBP) ${ }^{1}$ isolated from rabbit serum (15) and recently cloned (16) is suggested to be necessary for the observed enhance-

1. Abbreviations used in this paper: DIPE, diisopropyl ether; FPLC, fast protein liquid chromatography; KRPD, Krebs-Ringer phosphate dextrose (buffer); LBP, LPS-binding protein; TNF, tumor necrosis factor. 
ment. Furthermore, a cell surface target for LPS on the neutrophil appears to be CDI4.

\section{Methods}

Reagents. All reagents and plastic ware used in this assay were tested before use for the presence of LPS using the Limulus amebocyte lysate kit from Associates of Cape Cod, Inc. (Woods Hole, MA). This procedure detects as little as $0.01 \mathrm{ng}$ of LPS/ml. Sterile plastics and all reagents tested at the concentration used in the adherence assay were free of detectable LPS contamination.

The assay buffer employed was Krebs-Ringer phosphate buffer, $\mathrm{pH}$ 7.2 , with $0.2 \%$ dextrose (KRPD; $5 \%$ dextrose in $0.2 \%$ sodium chloride, injectable; Abbott Laboratories, North Chicago, IL). The salts comprising the buffer were purchased from Mallinkrodt Inc. (Paris, KY), and had undetectable LPS levels. All components were freshly diluted with LPS-free saline ( $0.9 \%$ saline for irrigation, Abbott Laboratories) on each experimental day.

LPS. LPS from Escherichia coli 0111:B4 and from Salmonella minnesota Re595 were purchased from List Biologicals (CA). E. coli K235 LPS, prepared by the method of McIntire et al. (17), was a kind gift of Dr. David Morrison, Department of Microbiology, Kansas University School of Medicine, Kansas City, KS. The lyophilized LPS was dissolved in LPS-free saline at $1 \mathrm{mg} / \mathrm{ml}$. Frozen aliquots were thawed and sonicated using a Sonicator Cell Disrupter (Ultrasonics, Inc., Plainview, NY) with a microtip at an amplitude setting of 2 for two 10-s periods before being diluted in assay buffer. Escherichia coli 0111:B4 LPS was specifically labeled by growing $E$. coli strain $\mathrm{J} 5$ to midlogarithmic phase in a basic salts medium containing $4.0 \mu \mathrm{Ci} / \mathrm{ml}$ of $\left[{ }^{3} \mathrm{H}\right]$ galactose as previously reported by Duncan et al. (18). Bacteria were harvested by centrifugation at $12,000 \mathrm{~g}$ and washed thrice in sterile PBS. Radiolabeled LPS was extracted from the bacteria by the hot phenol-water procedure of Westphal and Jann (19). Phenol-water extracted LPS was extensively dialyzed against distilled water, concentrated by ultrafiltration using a ym5 filter (Amicon, Beverly, MA) and diluted in sterile PBS. For other experiments, E. coli 0111:B4 LPS was radiolabeled with ${ }^{125}$ I using the benzimidate reaction (20). Both labeled LPS species were kind gifts from Dr. David Morrison.

Human and rabbit serum and plasma. Heterologous human serum was produced by clotting whole blood in LPS-free glass tubes. Serum was heat-treated at $56^{\circ} \mathrm{C}$ for $30 \mathrm{~min}$ and centrifuged at $500 \mathrm{~g}$ for $10 \mathrm{~min}$ to remove any precipitate. Plasma was prepared from citrated whole blood centrifuged at $800 \mathrm{~g}$ for $20 \mathrm{~min}$. The upper plasma layer was removed carefully, heat-inactivated, and centrifuged in a fashion similar to serum. Rabbit serum was obtained from normal animals and those undergoing an acute phase response as previously described (15).

Cells. Human umbilical vein endothelial cells were harvested by collagenase digestion according to the method of Gimbrone et al. (21) and grown and characterized as previously described (22). First passage cells were used after achieving confluence in microtiter wells.

Human blood neutrophils were prepared by a method which minimizes LPS exposure, using plasma-Percoll gradients as described by Haslett and co-workers (23). After isolation, neutrophils were labeled with ${ }^{111}$ In by first incubating $5 \mu \mathrm{Ci}^{111}$ In (New England Nuclear, Boston, MA) with $100 \mu \mathrm{l}$ of the chelating agent tropolone $\left(4 \times 10^{-3} \mathrm{M}\right)$ (Fluka AG Buchs, FRG) for $5 \mathrm{~min}$ at $23^{\circ} \mathrm{C}$, then adding the chelated ${ }^{111}$ In to $0.9 \mathrm{ml}$ of KRPD containing $3 \times 10^{7}$ neutrophils and incubating at $25^{\circ} \mathrm{C}$ for $5 \mathrm{~min}$. The cells were then washed with $50 \mathrm{vol}$ of KRPD and resuspended at a final concentration of $3 \times 10^{6} / \mathrm{ml}$.

Neutrophil adherence assay. The adherence assay developed for these studies was a modification of the monolayer adhesion assay previously reported by Tonnesen and co-workers (22). First-passage human endothelial cells were grown to confluence in microtiter tissue culture wells (Costar, Cambridge, MA) in M131 with 5\% FCS. Other wells were coated with serum by incubating with culture medium containing $5 \%$ FCS overnight. One to two hours before assay, the monolayers were washed twice and maintained in serum-free KRPD. Quadruplicate wells were prepared for each experimental variable to be tested.

After gentle suction aspiration of the serum-free medium from the assay wells, a $50-\mu l$ aliquot of ${ }^{111} \mathrm{In}$-labeled neutrophils $\left(3 \times 10^{-6} / \mathrm{ml}\right.$ in KRPD assay buffer) was added to each well (a ratio of five neutrophils to one endothelial cell), followed by a $25-\mu$ l aliquot of an appropriate concentration of LPS dissolved in assay buffer, as well as $25 \mu \mathrm{l}$ of an appropriate concentration of serum or plasma. Control wells containing only assay buffer, buffer plus LPS or buffer plus serum were also assayed for each experiment. The microtiter plates were incubated without agitation for $40 \mathrm{~min}$ (or for time intervals varying from 5 to 60 $\min$ ) at $37^{\circ} \mathrm{C}$ in a $5 \% \mathrm{CO}_{2}$ humidified tissue culture incubator. At the end of the incubation period, $100 \mu \mathrm{l}$ of $0.2 \%$ glutaraldehyde in PBS was carefully added to each well to fix the adherent cells. After $10 \mathrm{~min}$, the wells were washed twice with assay buffer to remove nonadherent neutrophils as described (22). The ${ }^{111}$ In-labeled neutrophils adherent to the cell monolayers were then harvested and counted in a gamma counter (Beckman Instruments, Inc., Fullerton, CA). Results were expressed as percent adherence $=(\mathrm{cpm}$ harvested $) /(\mathrm{cpm}$ added $) \times 100$.

Bead adherence assay. The adherence of albumin-coated latex beads to neutrophils in suspension was used as an assay of neutrophil adhesiveness which, as we have recently reported, does not require conformation of the neutrophil to a surface (24)..Results are expressed as $(a)$ the percentage of neutrophils which bound one or more beads and $(b)$ the average number of beads adherent to those neutrophils that bound beads. Neutrophil superoxide production and priming by LPS was assayed as described by Guthrie and co-workers (25).

Delipidation and delipoproteination of plasma. Fresh human serum from a pool of four donors was heat-inactivated and divided for extraction of lipid by two methods. Delipidation of the serum was achieved using the method of Cham and Knowles (26). Serum ( $5 \mathrm{ml}$ ) containing $0.1 \mathrm{mg} / \mathrm{ml}$ ethylene diamine tetraacetate (Sigma Chemical Co., St. Louis, MO) was added to $10 \mathrm{ml}$ of $60 \%$ diisopropyl ether (DIPE) (Fisher Scientific Co., Fair Lawn, NJ), and $40 \%$ butanol in an LPS-free glass tube. The tube was rotated end over end for $30 \mathrm{~min}$ at room temperature, then centrifuged at $2,000 \mathrm{rpm}$ for $2 \mathrm{~min}$ to clarify the layers. After transferring the organic layer to another tube the aqueous layer was extracted with an additional $5 \mathrm{ml}$ of DIPE for $10 \mathrm{~min}$ to remove traces of butanol. The organic material was dried under nitrogen and rehydrated in KRPD containing $4 \%$ human serum albumin. The aqueous phase was dialyzed in KRPD and the protein concentration was determined by the method of Lowry et al. (27). It was tested in the adherence assay at a final protein concentration of 70 $\mu \mathrm{g} / \mathrm{ml}$ along with the redissolved organic material, using a $1 \%$ solution of the original serum as a positive control.

Density centrifugation was used to remove the lipoprotein from serum by a modification of the method of Esko and Matsuoka (28). Briefly, an aliquot of serum was weighed and a saturated solution of $\mathrm{NaBr}$ (Fisher Scientific Co.) was slowly added until the density of the serum was increased to $1.21 \mathrm{~g} / \mathrm{ml}$. The serum was then centrifuged in a model L5-50 ultracentrifuge (Beckman Instruments, Inc., Palo Alto, CA) with an SW 50.1 rotor at $40,000 \mathrm{~g}$ for $36 \mathrm{~h}$. The lipoprotein layer was removed, the density was readjusted with the $\mathrm{NaBr}$ solution and the centrifugation was repeated. The delipoproteinated serum was dialyzed in KRPD, the protein concentration was determined and the serum was diluted and tested in the adherence assay at a final protein concentration of $70 \mu \mathrm{g} / \mathrm{ml}$.

Neutrophil pretreatment. Neutrophils were preincubated with LPS and serum and then assayed for adherence. In a $50-\mathrm{ml}$ plastic centrifuge tube (Becton-Dickenson \& Co., Oxnard, CA) a suspension of labeled neutrophils $\left(20 \times 10^{6}\right.$ in $\left.0.5 \mathrm{ml}\right)$ was mixed with $100 \mu \mathrm{l}$ serum and $100 \mu \mathrm{l}$ LPS ( final concentration $10 \mathrm{ng} / \mathrm{ml}$ ) and diluted to a final volume of $1 \mathrm{ml}$. Separate tubes containing neutrophils and buffer alone, LPS alone, or serum alone were prepared and all tubes were incubated for $10 \mathrm{~min}$ at $22^{\circ} \mathrm{C} .50 \mathrm{ml}$ of saline was added to each tube and they were centrifuged $5 \mathrm{~min}$ at $800 \mathrm{rpm}$, then resuspended in $\mathrm{KRPD}$ at $3 \times 10^{6} / \mathrm{ml}$. After this one high-volume wash, the pretreated 
cells were tested in the adherence assay, incubated with a buffer alone, LPS or serum alone, or the combination of LPS and serum.

Isolation and partial purification of plasma components. Human serum was fractionated by DEAE sepharose (Pharmacia, Inc., Piscataway, NJ) chromatography to limit the amount of other protein for immunoprecipitation experiments. The DEAE column was equilibrated with $0.01 \mathrm{M}$ PBS, $\mathrm{pH} 7.6$, and the serum was dialyzed in the same buffer overnight. The precipitate that formed during dialysis was removed by centrifugation at $1,000 \mathrm{~g}$ for $15 \mathrm{~min}$. Dialyzed serum ( 100 $\mathrm{ml}$ ) was added to a 300-ml column and eluted with a sodium chloride gradient from 0.02 to $1 \mathrm{M} \mathrm{NaCl}$ in PBS. Fractions were collected, assayed for protein concentration, adjusted to a final concentration of $70 \mu \mathrm{g} / \mathrm{ml}$, and tested for adherence-inducing activity. Active fractions were then reserved for immunoprecipitation studies. LBP was purified from rabbit serum as previously described (15).

Preparation of antisera to LBP. Polyclonal antisera to LBP were raised in goats as described (16), and IgG fractions prepared. Control antisera included nonimmune IgG, and antisera to rabbit IgG and fibronectin. Immunoprecipitation experiments using these sera were performed by incubating heparinized rabbit plasma with antisera $(10 \mathrm{mg} /$ $\mathrm{ml}$ ) to a final concentration of $2 \mathrm{mg} / \mathrm{ml}$, and incubated at $4^{\circ} \mathrm{C}$ for $18 \mathrm{~h}$, then centrifuged at $14,000 \mathrm{~g}$. Supernatants were collected and used to assay adherence.

LPS immunoprecipitation studies. Serum fractions from the DEAE column described previously that demonstrated the highest adherenceinducing activity were pooled and used for these experiments. A monoclonal antibody 5B10, which is directed at $E$. coli 0111:B4 LPS, was obtained courtesy of Dr. Chaunce Bogard, Centicor Corp., Malvern, PA, and was a kind gift of Dr. David Morrison. This antibody was used to immunoprecipitate the LPS and determine whether LPS itself was responsible for increasing neutrophil adherence, or whether LPS could produce an active plasma-derived component.

For immunoprecipitation, $2 \mu \mathrm{g} / \mathrm{ml}$ of $\left[{ }^{3} \mathrm{H}\right]$ LPS was incubated with $6.4 \mathrm{mg} / \mathrm{ml}$ of the pooled serum fraction (protein concentration to $\sim 10 \%$ serum) for $1 \mathrm{~h}$ at $37^{\circ} \mathrm{C}$. The material was then divided into $0.5-\mathrm{ml}$ aliquots and incubated with the monoclonal antibody at varying concentrations from 0 to $80 \mu \mathrm{g} / \mathrm{ml}$ for $30 \mathrm{~min}$ at $37^{\circ} \mathrm{C}$. To precipitate the antibody an excess $(10 \mathrm{mg})$ of washed Staphylococcus aureas (Immuno-Precipitin, Bethesda Research Laboratories, Gaithersburg, MD) was added and the mixture incubated for $30 \mathrm{~min}$ at room temperature. The precipitate was removed by centrifugation in an Eppendorf centrifuge (Beckman Instruments, Inc.) for $4 \mathrm{~min}$. The supernatant was separated into two aliquots. One was diluted and tested for activity in the adherence assay at a final LPS concentration equivalent to 10 $\mathrm{ng} / \mathrm{ml}$ and final protein concentration of $70 \mu \mathrm{g} / \mathrm{ml}$ for untreated con- trols. Another aliquot of each supernatant was counted on a Beckman LS3801 (Beckman Instruments, Inc.) beta counter to determine the amount of $\left[{ }^{3} \mathrm{H}\right]$ LPS left in each sample. The amount of $\left[{ }^{3} \mathrm{H}\right]$ LPS removed by the increasing concentrations of $5 \mathrm{~B} 10$ was compared with the decrease in adherence-inducing activity.

Fractionation of LPS. LPS was separated into different apparent molecular weight fractions by fast protein liquid chromatography (FPLC). 0111:B4 LPS ( $8 \mu \mathrm{g})$ was incubated at $37^{\circ} \mathrm{C}$ for $30 \mathrm{~min}$ with $200 \mu \mathrm{l}$ of serum and $250 \mathrm{ng}$ of ${ }^{125} \mathrm{I}-\mathrm{LPS}$ (containing $2 \times 10^{5} \mathrm{cpm}$ ). After incubation, the sample was injected into an FPLC ${ }^{\mathrm{c}}$ system (Pharmacia Inc.) equipped with a Superose 12 column perfused at $1.0 \mathrm{ml} / \mathrm{min}$ with KRPD. Fractions $(1.0 \mathrm{ml})$ were collected, protein measured by on-line analysis of the absorbance at $280 \mathrm{~nm}$, and ${ }^{125} \mathrm{I}$ counts assessed by gamma well counting of fractions. Samples containing different molecular weight LPS were frozen immediately at $-70^{\circ} \mathrm{C}$ and adherence activity studied by normalizing to equivalent numbers of ${ }^{125} \mathrm{I}$ counts. The column was standardized using molecular weight markers (Sigma Chemical Co.). In other experiments $55 \mathrm{ng}$ of LPS was incubated with $25 \mathrm{ng}$ of ${ }^{125} \mathrm{I}$-LPS and $3.2 \mathrm{mg}$ of human serum albumin in $200 \mu \mathrm{l}$ and treated similarly.

Statistics. Data were analyzed using a proprietary statistical package (Statistical Analysis System SAS, Cary, NC) operating on a VAX $11 / 750$ computer and are reported as mean \pm SE. The data for time, concentration dependence, cation dependence and lipoprotein depletion experiments were analyzed using the SAS general linear models (GLM) procedure. For all of these analyses, a multiple comparison of the treatments was done using the Ryan-Einott-Gabriel-Welsh multiple-range test (29) and considered significant if $P<0.05$.

\section{Results}

LPS-induced neutrophil adherence to endothelial cells: role of plasma. Absent plasma or serum, LPS concentrations of 1-10 $\mu \mathrm{g} / \mathrm{ml}$ were required to enhance adherence of isolated human neutrophils to endothelial cells. The presence of $1 \%$ heat-inactivated plasma or serum shifted the concentration dependence of the neutrophil adherence response to LPS. Fig. 1 demonstrates the concentration dependence of LPS from smooth strain $E$. coli 0111:B4 for stimulation of neutrophil adherence to both human umbilical vein endothelial cells (Fig. $1 A$ ), and serum-coated plastic (Fig. $1 B$ ). In the presence of plasma the response is $2-3 \operatorname{logs}$ more sensitive than when LPS is incubated with neutrophils in the presence of buffer alone. Experiments

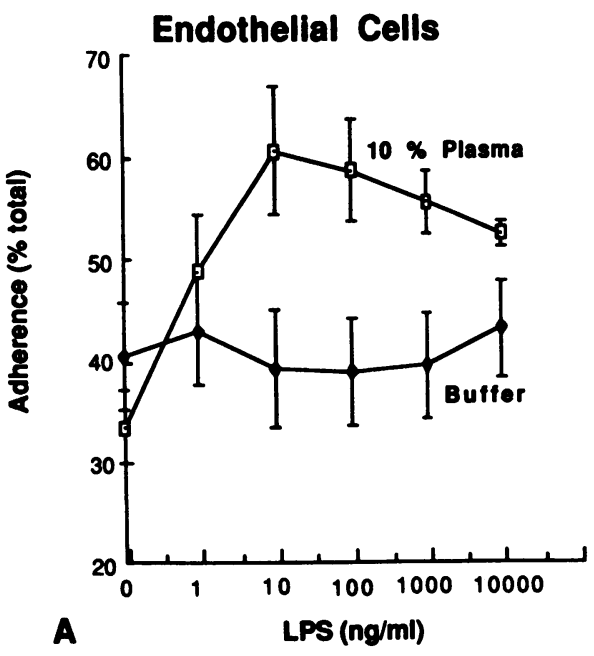

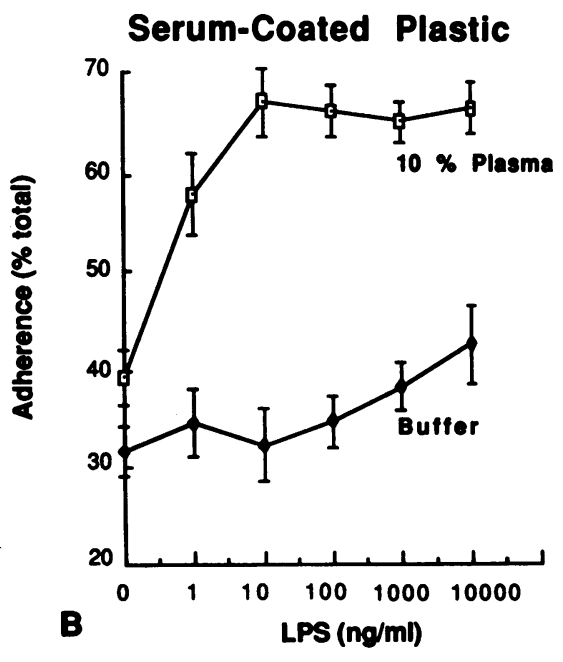

Figure 1. Neutrophil adherence to endothelial or serum-coated plastic surfaces as a function of 0111:B4 LPS concentration in the presence and absence of $10 \%$ plasma. Labeled neutrophils $\left(5 \times 10^{5}\right.$ per well $)$ were incubated with the LPS concentration indicated on the logarithmic abcissa for $\mathbf{4 0}$ $\mathrm{min}$ in microtiter wells. $(A)$ Monolayers of human umbilical vein endothelial cells. $(B)$ Serum-coated plastic. Shown is the mean \pm SEM of seven determinations. The effect of plasma is significantly different from that of buffer $(P<0.05)$ by two-way ANOVA. In plasma-treated cells the effect of LPS is significant, detectable $(P<0.05)$ at $10 \mathrm{ng} / \mathrm{ml}$. 
using LPS from $E$. coli $\mathrm{k} 235$ exhibited similar dose-responses, as did LPS from the mutant $S$. minnesota Re595 (which is mostly lipid A) (data not shown). Detectable enhancement was seen at $0.1 \%$ plasma, and $1 \%$ was as active as $10 \%$ (data not shown). Serum and plasma were equally active, and the activity was stable during heat-treatment at $56^{\circ} \mathrm{C}$ for $30 \mathrm{~min}$. These data suggest that LPS, acting via its lipid $\mathrm{A} / \mathrm{KDO}$ component, required plasma as a cofactor to increase adherence. However, adherence induced by FMLP was unaltered in the presence of $1-10 \%$ plasma or serum (data not shown), suggesting that the effect was not exerted on adherence per se.

In the absence of plasma, LPS-induced increases in neutrophil adherence to either serum-coated plastic or endothelial cells required at least $60 \mathrm{~min}$ for the full expression of adherence (Fig. 2). However, in the presence of $10 \%$ plasma, $1 \mu \mathrm{g} /$ $\mathrm{ml}$ LPS produced a detectable increase in adherence as early as $15 \mathrm{~min}$ after exposure (Fig. $2 \mathrm{~B}$ ), whereas $10 \mathrm{ng} / \mathrm{ml} \mathrm{LPS} \mathrm{in-}$ duced adherence at $30 \mathrm{~min}$ (Fig. $2 \mathrm{~A}$ ). The differences between buffer and plasma-treated cells are even more apparent at low concentrations of LPS $(10 \mathrm{ng} / \mathrm{ml}$, Fig. $2 A)$. The relative slowness of development of LPS-induced adherence contrasts with FMLP-induced adherence where adherence is detectable within seconds (22).

To compare the adherence induced by LPS and a more traditional stimulus, the cation requirements for binding were determined in the presence of serum. As shown in Table $\mathbf{I}$, in the absence of $\mathrm{Ca}^{++}$and $\mathrm{Mg}^{++}$(in the presence of the chelator EDTA) the baseline adherence was lowered, but LPS was still able to increase adherence twofold $(P<0.01)$. The addition of $\mathrm{Mg}^{++}(1 \mathrm{mM})$ was accompanied by an increase in the baseline adhesion, and a similar twofold increase in adherence with LPS. In the presence of $\mathrm{Mg}^{++}$, addition of $\mathrm{Ca}^{++}$had an added effect to increase LPS-induced adherence, comparable in magnitude to that observed with unchelated serum in Fig. $1 B$.

Pretreatment studies. We carried out pretreatment studies to determine whether the effect of serum and LPS was concerted or sequential, and whether the combination acted on the
Table I. Effect of Divalent Cations on LPS-induced Neutrophil Adherence

\begin{tabular}{lccc}
\hline & \multicolumn{3}{c}{ Neutrophil adherence } \\
\cline { 2 - 4 } Simulus & No divalent cations ${ }^{*}$ & $\mathrm{Mg}^{++\ddagger}$ & $\mathrm{Ca}^{++}$and $\mathrm{Mg}^{++\xi}$ \\
\hline & $\%$ & \\
Buffer & $13.8 \pm 3.8$ & $27.6 \pm 6.0^{\prime \prime}$ & $27.1 \pm 4.9^{\prime \prime}$ \\
LPS & $24.9 \pm 3.6^{*}$ & $52.4 \pm 11.6^{1}$ & $70.0 \pm 3.6^{1}$ \\
\hline
\end{tabular}

Adherence to serum coated plastic was tested in the presence of $10 \%$ platelet-poor plasma. The LPS concentration was $100 \mathrm{ng} / \mathrm{ml}$ and the adherence assay was incubated for $40 \mathrm{~min}$. ${ }^{*}$ Buffer (KRPD) without added $\mathrm{Ca}^{++}$or $\mathrm{Mg}^{++}$, and with a $0.5 \mathrm{mM}$ EDTA. ${ }^{\ddagger} \mathrm{KRPD}$ without added $\mathrm{Ca}^{++}$, but containing $1.2 \mathrm{mM} \mathrm{MgSO}_{4}$, and with $0.25 \mathrm{mM}$ EGTA. ${ }^{\S} \mathrm{KRPD}$ with $0.93 \mathrm{mM} \mathrm{CaCl}_{2}$ and $1.2 \mathrm{mM} \mathrm{MgSO}_{4}$ as used for all other assays in this study. " $P<0.01$ compared to buffer. ' $P$ $<0.01$ compared to condition of no divalent cations.

neutrophil or the endothelial cell. Neutrophils demonstrated a marked increase in adherence only when incubated with LPS and serum together, even if the cells were washed with buffer after a 5-min incubation period (data not shown). However, no other sequence or combination of incubations with LPS, serum, or buffer produced the same effects (data not shown). Over the time course we studied, treatment of endothelial cells or serum-coated plastic (data not shown) with LPS and serum or serum alone, followed by washing, did not result in enhanced adherence when neutrophils were added subsequently, unless plasma and LPS were reintroduced into the assay (data not shown). These data argue for a concerted interaction among neutrophils, serum and LPS in the initiation of adherence.

Immunoprecipitation of LPS. Experiments utilizing radiolabeled 0111:B4 LPS and a monoclonal antibody directed

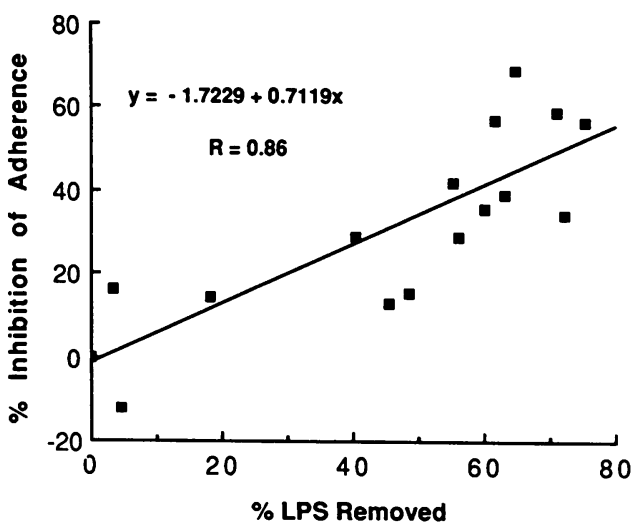

Figure 3. Relationship between immunoprecipitation of $\left[{ }^{3} \mathrm{H}\right]$ LPS from LPS-plasma incubation mixtures and inhibition of neutrophil adherence (see Methods). LPS incubated with plasma for $30 \mathrm{~min}$ was exposed to the monoclonal antibody $5 \mathrm{~B} 10$ and precipitated with protein A-sepharose. Degree of immunoprecipitation was determined by ${ }^{3} \mathrm{H}$ counts in pellet and supernatant material. Supernatant material was used to induce neutrophil adherence, and \% inhibition of adherence determined. 

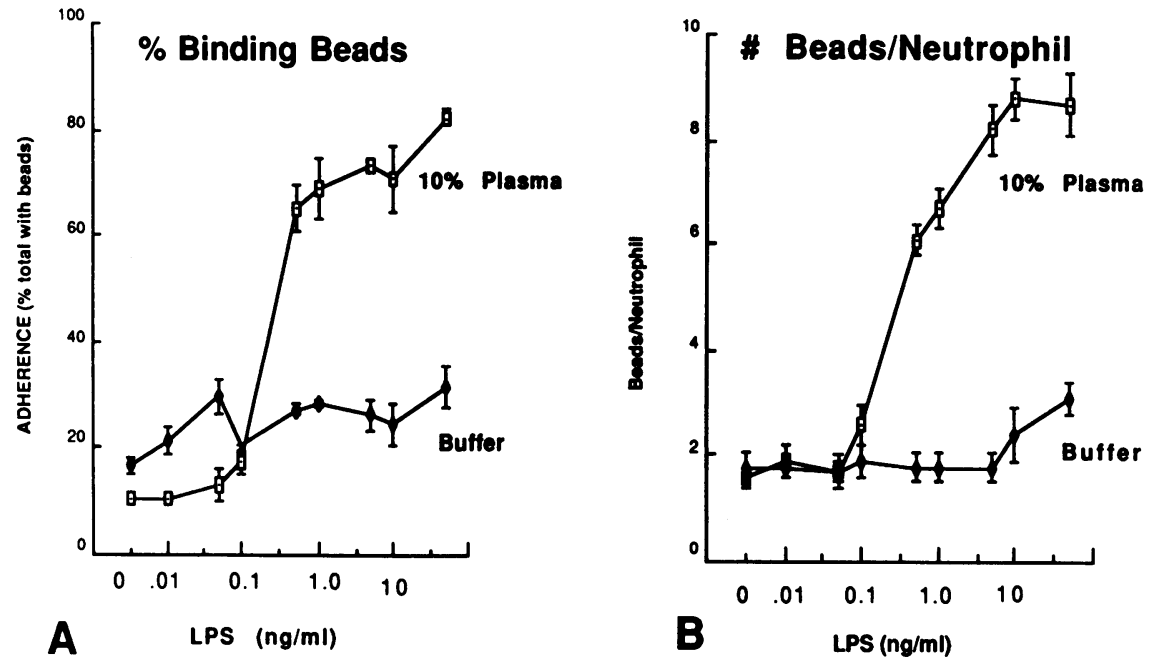

Figure 4. Adherence of albumin-coated beads to the neutrophil surface in the presence or absence of $10 \%$ plasma as a function of LPS concentrations (see Methods). ( $A$ ) Percent of the neutrophils binding beads. $(B)$ Mean number of beads per cell. The effect of plasma is significant for either condition $(P$ $<0.05$ ) by two-way ANOVA.

against that LPS were designed to determine if LPS was an integral part of the adherence-inducing activity, or merely modified a plasma component to make it active. After incubating radiolabeled $\left[{ }^{3} \mathrm{H}\right]$ LPS with partially purified serum, LPS was precipitated from the mixture by varying amounts of monoclonal antibody, and the supernatant tested for both adherence-inducing activity and the amount of $\left[{ }^{3} \mathrm{H}\right]$ LPS remaining. Fig. 3 demonstrates that as LPS is bound and precipitated from the mixture, the adherence-inducing activity decreases, and there is a correlation between the amount of LPS removed and the inhibition of adherence. The addition of protein A sepharose beads alone had no effect on the apparent activity of the LPSplasma incubation in the absence of 5B10 antibody (data not shown).

Adhesion of beads to the neutrophil surface. The adherence of albumin-coated latex beads to the neutrophil surface in suspension was studied, as it allowed us to determine the distribution of the adhesive phenotype within the population, as well as to ascertain whether adherence required organization of the cell onto a flat surface (spreading). Using a system that we have recently reported (24), LPS concentrations of 100-1,000 ng/ $\mathrm{ml}$ in buffer increased binding of beads to the neutrophil expressed either as a percentage of the neutrophils that bind any beads, or as the average number of beads bound. Fig. 4 demonstrates that in the presence of $10 \%$ plasma, the binding of beads to the surface was dramatically increased by concentrations of LPS between 0.1 and $1 \mathrm{ng} / \mathrm{ml}$, concentrations well within those detected in sepsis (30). Not only was the percentage of cells that bind beads increased from $<20 \%$ to $>80 \%$, but the average number of beads bound to those neutrophils was also markedly increased from fewer than two beads per cell, to more than six beads per cell.

Effect of plasma on the physicochemical properties of LPS: relationship to activity. In light of the pioneering studies of Rudbach and co-workers ( 31 ) suggesting that plasma disaggregated LPS, we questioned whether the apparent molecular mass of LPS would be affected by this interaction. The fractionation of LPS on gel filtration FPLC is shown in Fig. 5. Fig. $5 \mathrm{~A}$ depicts the elution pattern of ${ }^{125}$ I-labeled 0111:B4 LPS from a Superose 12 column. Essentially all the LPS elutes as a single peak in the void volume. In contrast, the observed elution pattern of LPS incubated with serum for $30 \mathrm{~min}$ at $37^{\circ} \mathrm{C}$ was altered. Approximately $50 \%$ of the ${ }^{125}$ I-labeled LPS was found in lower molecular mass fractions of $\sim 100 \mathrm{kD}$. The elution profile of the serum proteins is shown in the same figure.

We also measured the adherence-increasing activities of the high and low molecular mass fractions. As shown in Fig. 6, 0111:B4 LPS at $100 \mathrm{ng} / \mathrm{ml}$ was able to increase adherence of neutrophils for beads only in the presence of $1 \%$ serum. Similarly, $100 \mathrm{ng} / \mathrm{ml}$ LPS from the high molecular fractions (fraction 9 in Fig. $5 B$ ) was only effective at increasing adherence in the presence of $1 \%$ serum. In contrast, the low molecular weight fractions (fraction 13 in Fig. $5 B$ ) increased adherence in the absence of any added serum. Thus, LPS incubated with serum is shifted to lower molecular mass components that appear to increase adherence.

Characterization of the plasma activity. The best-studied interaction between LPS and plasma has been that between LPS and $\operatorname{HDL}(32,33)$. To determine whether formation of a complex between LPS and HDL could account for the enhancement provided by plasma, we depleted plasma of lipoproteins. As shown in Table II, plasma depleted of lipoproteins retained the ability to enhance the action of LPS on neutrophil adherence, suggesting that interaction of LPS with HDL did not account for the observed activity.

Recently, one LBP has been purified from rabbit serum (15) and cloned (16). We measured the ability of purified rabbit LBP to replace the effect of serum in studies of LPS-induced neutrophil adherence (in this case to serum-coated plastic). As shown in Fig. 7, LBP (10-2,000 ng/ml) induced a concentration-dependent enhancement of the responses to both 0111:B4 and Re595 LPS. These data suggested that LBP might be an important component of the plasma processing of both Re595 and 0111:B4 LPS. To further address this latter question, rabbit serum was depleted of functional LPB. Depletion of LBP by complexing with goat anti-rabbit LBP (GAR-LBP) abolished the ability of normal rabbit serum to enhance the effect of 0111:B4 LPS (Fig. 8), while incubation of rabbit serum with goat anti-rabbit IgG (GAR-IgG) or goat anti-rabbit fibronectin $(G A R-F n)$ was without effect, suggesting that LBP is neces- 

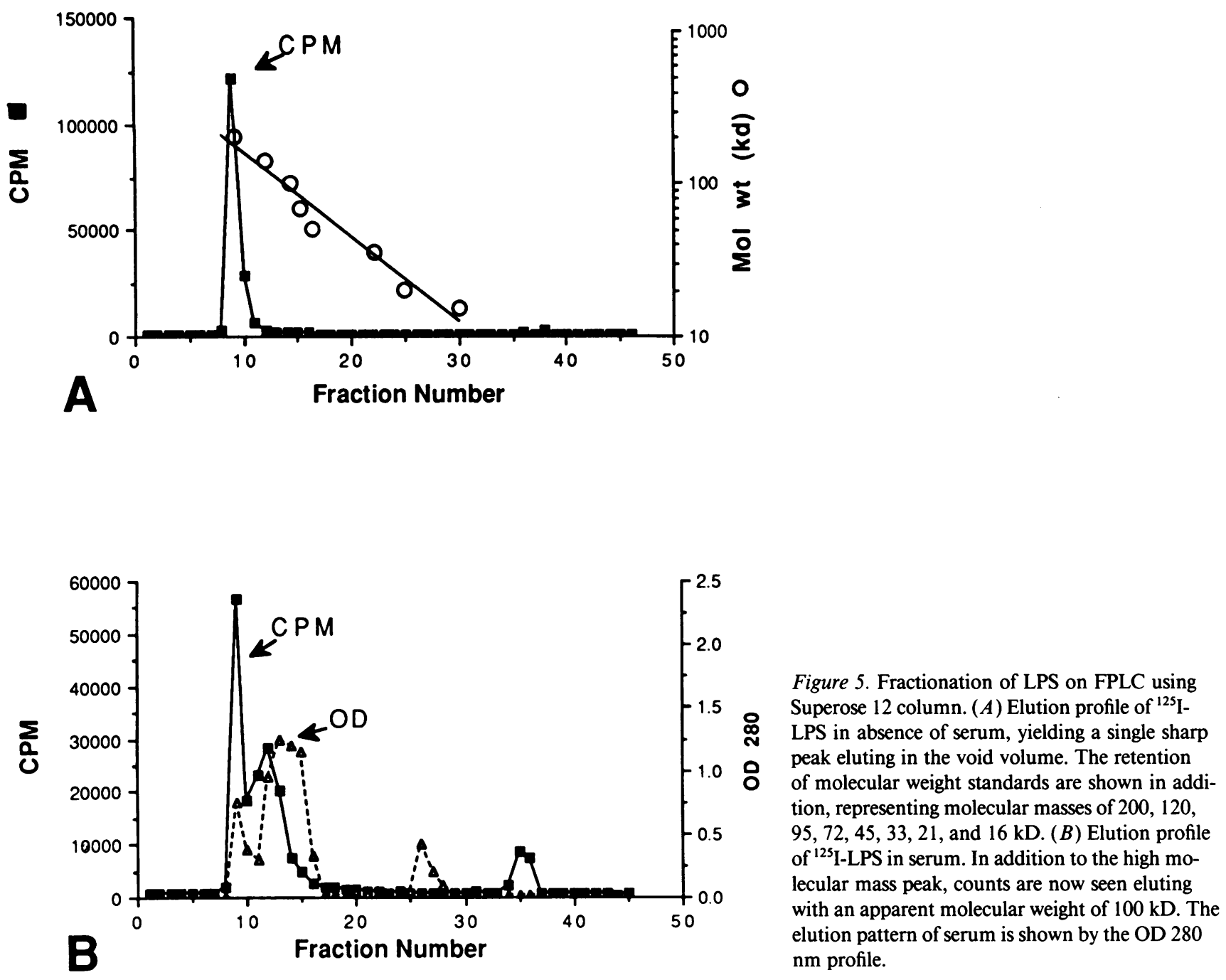

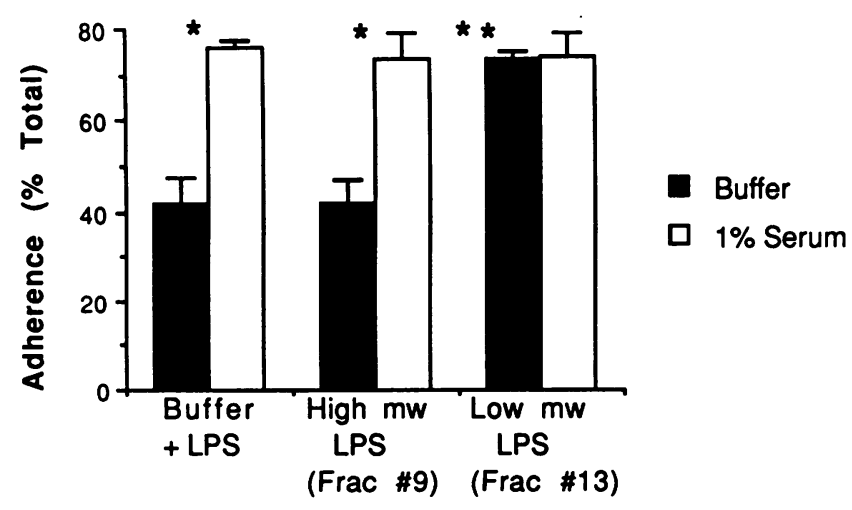

Figure 6. Biologic activity (stimulation of bead adherence) of various fractions in Figure 5. Activity of column buffer with addition of 100 $\mathrm{ng} / \mathrm{ml}$ 0111:B4 LPS in the presence or absence of $1 \%$ serum is compared with activity of high molecular weight LPS ( fraction 9) or low molecular weight LPS (fraction 13) as in Figure 5. Only the low molecular weight LPS is active absent added serum. ${ }^{*} P<0.05$ when compared to buffer-containing wells. ${ }^{* *}$ No difference between plasma and buffer-containing conditions. sary for rabbit serum enhancement of LPS-induced neutrophil adherence.

Targets of LPS in the context of LBP. Since neutrophil preparations may contain as much as $0.5-1 \%$ monocytes, we considered the possibility that tumor necrosis factor (TNF), released from LPS-exposed monocytes, might stimulate neutrophil adherence (34). Using the bead adhesion system, we first determined that a monoclonal anti-TNF antibody, supplied courtesy of Richard Ulevitch (Scripps Institute, La Jolla, CA), and a kind gift of Peter M. Henson (National Jewish Center, Denver, CO), was able to prevent TNF-induced neutrophil adherence (data not shown). Used in the same concentration, however, this antibody had no effect on the number of beads bound to the neutrophil surface in response to LPS in $10 \%$ serum, nor did it inhibit priming of neutrophils for enhanced superoxide secretion (another function enhanced by plasma [35] perhaps secondary to LBP [36]) (data not shown).

The cellular target for complexes of LPS and LBP has recently been suggested to be CD14 (37), a monocyte differentiation antigen that has been shown to be expressed and up-regu- 


\begin{tabular}{lllcr}
\hline & \multicolumn{4}{c}{ Neutrophil adherence } \\
\cline { 2 - 5 } \multicolumn{1}{c}{ Stimulus } & \multicolumn{1}{c}{ Buffer } & $1 \%$ serum & 1\% extracted serum & $1 \%$ delipoproteinated serum \\
\hline & & & $\%$ \\
Buffer & $35.1 \pm 8.4$ & $25.4 \pm 6.1$ & $36.1 \pm 11.0$ & $18.2 \pm 3.3$ \\
LPS $(100 \mathrm{ng} / \mathrm{ml})$ & $40.0 \pm 10.4$ & $68.2 \pm 7.1^{*}$ & $62.6 \pm 6.5^{*}$ & $63.6 \pm 7.7^{*}$ \\
\hline
\end{tabular}

See Methods for extraction procedures. The adherence of neutrophils to serum-coated plastic wells was studied after 40 min at $37^{\circ} \mathrm{C} \pm \mathrm{LPS}$ at 100 $\mathrm{ng} / \mathrm{ml}$. The protein concentrations of all serum samples were adjusted to $70 \mu \mathrm{g} / \mathrm{ml}$. ${ }^{*}$ Different from buffer $(P<0.05)$.

lated on neutrophils by a variety of stimuli (38). In order to determine whether LPS stimulation of adherence required interaction with CD14, we incubated neutrophils with two antibodies directed against different epitopes of this surface component. The antibody Mo2, which labels neutrophils poorly, had no effect on neutrophil adherence induced by LPS. In contrast, MY4, which binds to neutrophils (data not shown) and labels a single 52-kD band from neutrophil membranes (Fig. 9, inset) completely inhibited LPS-induced neutrophil adherence (Fig. 9). Furthermore, in data not shown, staining of neutrophils by MY4 was abrogated by prior incubation of the cells with a phosphotidylinositol-specific phospholipase $\mathrm{C}$ but not by a phosphotidylcholine-specific phospholipase $C$, consistent with data from other cells that CD14 is attached by a phosphotidylinositol linkage. Pretreatment with the phosphatidylinositolspecific, but not the phosphatidylcholine-specific phospholipase $\mathrm{C}$ abrogated the adhesive response to LPS, but had no effect on the adhesive response to FMLP (data not shown).

\section{Discussion}

LPS has been shown to interact with a number of plasma components, including complement proteins (12), lipoproteins (32), albumin (39), native anti-LPS antibodies (40), and recently described LBPs (15). Early studies of the mechanisms
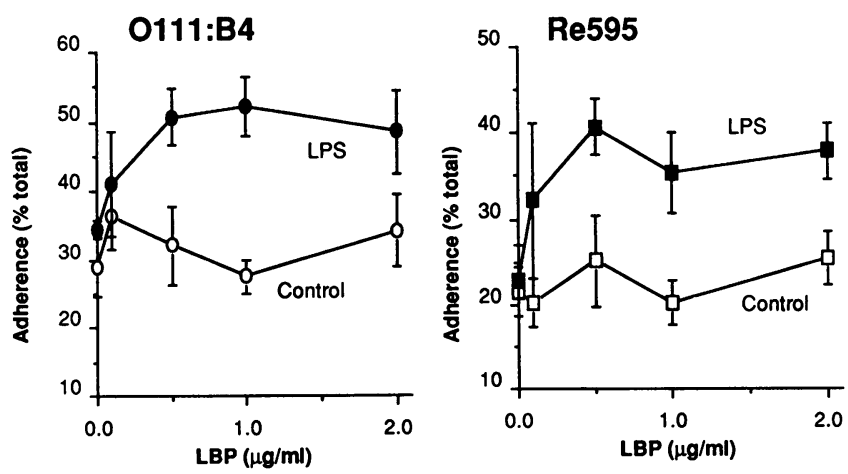

Figure 7. Effect of purified LBP on enhancement of LPS-induced neutrophil adherence to serum-coated plastic wells. Concentrations from 0 to $2,000 \mathrm{ng} / \mathrm{ml}$ LBP were incubated with neutrophils in buffer $(0)$ or $100 \mathrm{ng} / \mathrm{ml}$ of either 0111:B4 LPS $(A)$ or $\operatorname{Re} 595 \operatorname{LPS}(B)(\square)$. The enhancement seen with LBP in the presence of LPS is significant at $P<0.01$ by two-way ANOVA. by which LPS increases neutrophil adherence focused on the ability of LPS to activate complement and generate potent neutrophil chemotaxins (12). However, Dahinden and colleagues (10) demonstrated that LPS could increase adherence in the presence of heat-inactivated plasma wherein complement activation was prevented. Haslett et al. (13) extended the studies of Dahinden et al. (10) by incubating isolated rabbit neutrophils with LPS in the presence of heat-treated plasma, and then after washing, reinfusing them into recipient rabbits. In contrast to control neutrophils incubated ex vivo, the LPS-treated cells were retained for long periods of time within the lung vasculature, and there was no evidence of complement activation on the surface of neutrophils. These two studies present persuasive evidence that LPS-induced neutrophil adherence, and sequestration of neutrophils in vascular beds, proceeds by a complement-independent effect. In this study, we investigated the role of plasma or serum components in the modulation of LPS-induced neutrophil adherence. We found that although LPS in-

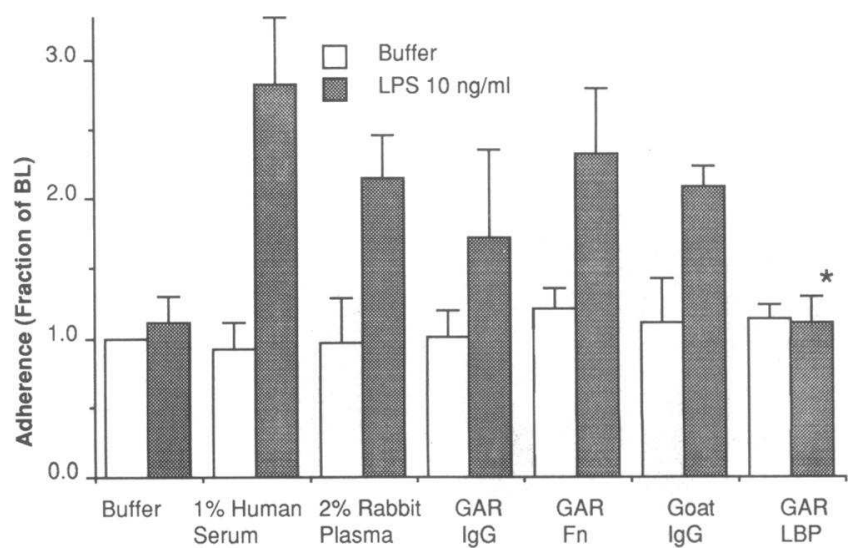

Figure 8. Effect of antibody (goat anti-rabbit [GAR]) to LBP and other serum components on enhancement of LPS-induced adhesion, expressed as a fraction of the baseline value. Both $1 \%$ human serum and $2 \%$ heparinized rabbit plasma allow for increased adherence with $10 \mathrm{ng} / \mathrm{ml} \mathrm{LPS}$, and rabbit plasma was used for all other conditions. To deplete, IgG fractions of antisera were incubated at $2 \mathrm{mg} / \mathrm{ml}$ with rabbit plasma overnight at $4^{\circ} \mathrm{C}$. The plasma was then centrifuged, then coincubated at $2 \%$ final concentration without (open bars) or with $10 \mathrm{ng} / \mathrm{ml}$ O111:B4 LPS (solid bars) in an adherence assay. Control sera include antisera (goat anti-rabbit $[G A R]$ ) directed against rabbit IgG $(G A R \operatorname{IgG})$ and fibronectin $(G A R F n)$, and goat IgG. Wells exposed to goat anti-rabbit LBP $(G A R L B P)$ are significantly different by two-way ANOVA $(P<0.05)$. 


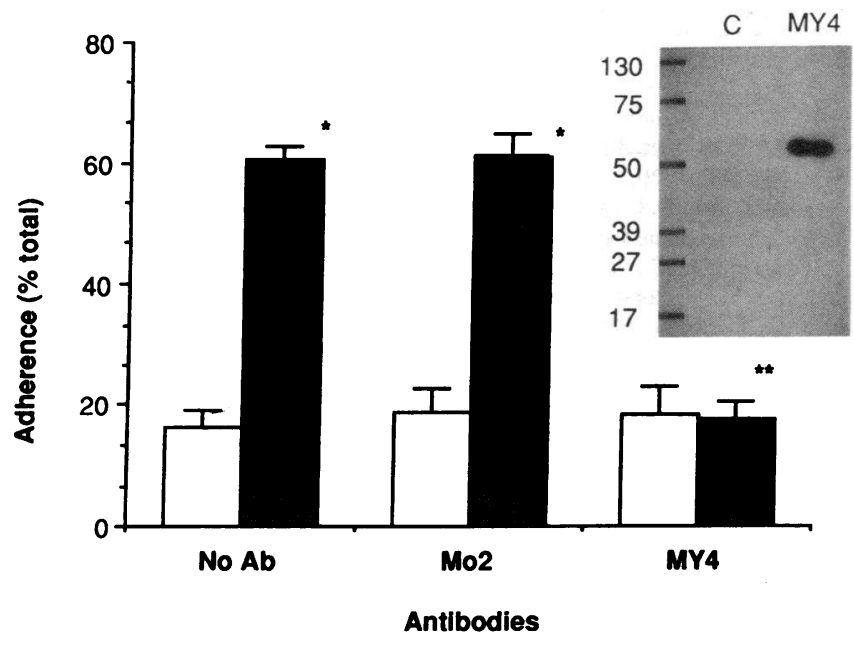

Figure 9. Effect of antibodies directed against CD14 on the adhesive response to LPS. Neutrophils were incubated in $1 \%$ serum in buffer without or with $30 \mu \mathrm{g} / \mathrm{ml}$ of the indicated antibody in the presence (open bars) or absence (solid bars) of $10 \mathrm{ng} / \mathrm{ml} \mathrm{O111:B4} \mathrm{LPS.} \mathrm{(Inset)}$ Western blot of neutrophil membranes blotted with MY4 or IgG2b control $(C)$. Neutrophil membranes were electrophoresed on a 4-15\% acrylamide gradient gel, transferred to nitrocellulose, and blotted with either control mouse IgG2b (C) or MY4 and developed using an enhanced chemiluminescence technique. ${ }^{*}$ Different from no LPS condition. **Different from other LPS conditions by two-way ANOVA.

creased neutrophil adherence in buffer, ${ }^{2}$ this effect required concentrations of LPS in a range far above those estimated to exist in vivo, and required $60 \mathrm{~min}$, whereas a number of workers have shown that neutropenia occurs within 5-15 min in vivo. In the presence of even $1 \%$ serum or plasma, however, a consistent increase in adherence was seen at concentrations of $10 \mathrm{ng} / \mathrm{ml}$, and the induction of adhesion accelerated, such that increased adhesion was detectable in $15 \mathrm{~min}$, and well established by $30 \mathrm{~min}$. Plasma and serum were equally effective, and heat treatment $\left(56^{\circ} \mathrm{C}\right.$ for $30 \mathrm{~min}$ ) to prevent complement activation did not diminish the response. The ability of plasma to enhance neutrophil adhesiveness to surfaces appears to be mediated almost entirely on the neutrophil, at least during the times investigated in this study.

The interaction of LPS and plasma components with the neutrophil surface appears to involve a concerted response among all three components. An adhesive neutrophil was generated only when neutrophils, plasma, and LPS were present together, although only a brief exposure $(5 \mathrm{~min}$ ) of neutrophils to LPS and plasma was required to permit the adhesive reaction to proceed over the subsequent $30 \mathrm{~min}$.

There are several possible explanations for the observed effects of these plasma constituents. LPS might convert a plasma component from an inactive to an active component, analogous to its ability to activate complement. That this activity is not complement is clear from the heat treatment studies. However, such an intermediate could not be labile, since the

2. Tonneson, M. G., D. C. Anderson, and G. S. Worthen. Lipopolysaccharide-induced neutrophil adherence to endothelial cells in vitro: mechanisms of adhesion. Manuscript in preparation. incubation of LPS and plasma forms an activity which is stable for $1 \mathrm{~h}$. Furthermore, we would expect that if an intermediate were formed from a plasma component, LPS itself would then be superfluous. In contrast, treatment of the "activated" plasma-LPS with a monoclonal antibody that binds LPS abolishes the activity, suggesting that it resides at least partly within LPS itself.

Accordingly, it seems likely that the active fraction represents LPS which is modified by plasma through binding or disaggregation. Rudbach and colleagues (31), over 20 years ago, argued that an important initial event in LPS detoxification was non-enzymatic disaggregation of LPS micelles. Our data suggest that LPS disaggregation is an important part of processing by serum components. Disaggregation of $\operatorname{Re} 595$ LPS aggregates ( $10^{6}$ daltons) into smaller molecular mass aggregates in delipoproteinated serum has been demonstrated by Ulevitch and colleagues (32).

Here we have presented evidence confirming that smooth LPS was converted from high molecular mass aggregates to lower molecular mass aggregates $(100 \mathrm{kD})$ when incubated with serum. Furthermore, the LPS so converted appeared to be more active than native LPS in the absence of added serum. While this might reflect a greater number of molecules available for binding, it cannot entirely account for the shift in dose-response characteristics. Accordingly, it seems apparent that both the aggregation state and the nature of the complex formed between LPS and those plasma constituents with which it interacts are crucial determinants of the functional activity that results (see also reference 41 ).

The serum components responsible for these alterations are beginning to be characterized, and are the subject of current study. The LBP identified in acute phase rabbit serum is an attractive candidate (15), as it is the only protein so far shown to bind to LPS at physiological concentrations. It has been shown to bind avidly to Re595 LPS, and has recently been shown to enhance the effects of both O111:B4 and Re595 LPS on monocytes (16). Here we have demonstrated the ability of this protein to enhance LPS-induced neutrophil adherence. Furthermore, the ability of rabbit serum to enhance LPS-induced adherence of neutrophils is abolished by antibodies against this protein. These data suggest that LBP may be necessary for serum enhancement of LPS activity. Whether it is the only such molecule in rabbit serum is unclear, and its precise role in human serum remains uncertain. Definitive elucidation of these complex events in the human requires purification of human LBP, and separation of all relevant activities. It is of interest that purified LBP, even in high concentrations, does not increase the activity of LPS as much as does serum containing lower concentrations of LBP. These observations raise the possibility that other serum components, such as albumin (42, 43) may also contribute to the response of neutrophil populations.

Recent work suggests that the complex of LPS with LBP binds to CD14 on the surface of the monocyte (37) and the neutrophil (38), supporting the notion that it is not merely the smaller size but different presentation that enhances activity. A recent study by Wright and Ramos (38) indicates that the complex of LPS and LBP binds to CD14 on the neutrophil surface and induces adherence through upregulation of CR3. Here we have demonstrated that antibodies directed against one epitope of CD14 block the response to serum-enhanced neutrophil ad- 
hesive response to LPS. Furthermore, treatment of the neutrophil with phosphatidylinositol-specific phospholipase $\mathrm{C}$ that decreases staining by anti-CD14 antibodies also prevented the neutrophil response to serum.

Many adhesive responses demonstrated for neutrophils exposed to more traditional neutrophil stimuli appear to require the involvement of the CD11/CD18 complex of adhesive glycoproteins (44). Although not addressed in this study, the mechanism by which LPS increased adherence has been shown by us to also involve this complex. ${ }^{2}$ Furthermore, surface expression of CD18 was enhanced by serum in a fashion parallel to the increase in adhesion shown here. ${ }^{2}$ These data suggest an important role for the CD11/CD18 complex in mediating neutrophil adherence induced by LPS in serum. A role for LPS and LBP in the activation of CD11/CD18 was suggested recently by Wright and colleagues (38).

New information from several studies now permits a more detailed appreciation of the response of the organism to LPS. LBP appears essential for the serum enhancement of LPS induction of adherence (this work) or priming (36) in neutrophils, or of TNF synthesis by monocytes (37). The formation of an LPS-LBP complex (16) then allows interaction with CD14 on both the surface of the neutrophil (this work and see also reference 38 ) and monocyte (37). Finally, this interaction leads to increased adhesiveness by the neutrophil, due in part to up-regulation of CD1 1 / 18 (38). ${ }^{2}$ Our study suggests that LBP in serum is not only capable of enhancing LPS-mediated adherence, but functions as a critical part of the serum response to LPS, and that LPS modified by serum or plasma requires interaction with CD14 on the surface of leukocytes. Accordingly, studies of the interaction between LPS and serum components may yield clues to the pathogenesis of a variety of infectious and inflammatory disorders.

\section{Acknowledgments}

The authors acknowledge the expert technical assistance of Lee Smedly, Scott Young, and Michele Kus. Additionally, the author wishes to acknowledge stimulating discussions with David Morrison, Marcia Tonnesen. Richard Ulevitch and Peter Henson. John Labreque provided statistical expertise, and Peggy Hammond, secretarial expertise. The monoclonal anti- $E$. coli 0111 LPS antibody used in these studies was provided courtesy of Dr. Chaunce Bogard, Centicor Corp., Malvern, PA, and was a kind gift of Dr. David Morrison, Department of Microbiology, Kansas City, KS. Dr. Morrison also kindly provided the labeled LPS species used. The monoclonal anti-TNF referred to was supplied courtesy of Dr. Richard Ulevitch, Scripps Institute, La Jolla, CA, and was a kind gift of Peter M. Henson, National Jewish Center, Denver, CO.

This work was supported by a SCOR in ARDS, HL 40784, and by USPHS grants GM-37696, AI-15136, AI-24565, and AI-25563.

\section{References}

1. Fowler, A. A., G. T. Hammon, K. N. Good, M. Baird, D. Eberle, T. L. Petty, and T. M. Hyers. 1983. The adult respiratory distress syndrome: risk with predispositions. Ann. Intern. Med. 98:593-597.

2. Brigham, K., W. Woolverton, L. Blake, and N. C. Staub. 1974. Increased sheep lung vascular permeability caused by Pseudomas bacteremia. J. Clin. Invest. 54:792-804.

3. Richman, A. V., J. Gerber, and J. Y. Balis. 1980. Peritubular capillaries: a major target site of endotoxin-induced vascular injury in the primate. Lab. Invest. 43:327-332.

4. Muller-Berghaus, G., E. Bohn, and W. Hobel. 1976. Activation of intravas- cular coagulation by endotoxin: the significance of granulocytes and platelets. $\mathrm{Br}$. J. Haematol. 33:213.

5. Ulevitch, R. J., C. G. Cochrane, P. H. Henson, D. C. Morrison, and W. F. Doe. 1975. Mediation systems in bacterial lipopolysaccharide-induced hypotension and disseminated intravascular coagulation. I. The role of complement. $J$. Exp. Med. 142:1570.

6. Morrison, D. C., and R. J. Ulevitch. 1978. The effect of bacterial endotoxins on host mediation systems. Am. J. Pathol. 93:527-617.

7. Heflin, A. C., Jr., and K. L. Brigham. 1981. Prevention by granulocyte depletion of increased vascular permeability of sheep lung following endotoxemia. J. Clin. Invest. 68:1253-1260.

8. Florey, H. W., and L. H. Grant. 1961. Leukocyte emigration from small blood vessels stimulated with ultraviolet light: An electron microscope study. $J$. Pathol. Bacterial. 82:13-17.

9. Stetson, C. A., Jr. 1951. Studies on the mechanism of the Schwartzman phenomenon. Certain factors involved in the production of the local hemorrhagic necrosis. J. Exp. Med. 93:489-504.

10. Dahinden, C., C. Galanos, and J. Fehr. 1983. Granulocyte activation by endotoxin. I. Correlation between adherence and other granulocyte functions, and role of endotoxin structure on biologic activity. J. Immunol. 130:857-862.

11. Pohlman, T. H., K. A. Stanness, B. G. Beatty, H. D. Ochs, and J. M. Harlan. 1986. An endothelial cell surface factor(s) induced in vitro by lipopolysaccharide, interleukin-1, and tumor necrosis factor increases neutrophil adherence by CDw18-dependent mechanism. J. Immunol. 130:4548-4553.

12. Morrison, D. C., and L. F. Kline. 1977. Activation of the classical and properdin pathways of complement by bacterial lipopolysaccharides (LPS). $J$. Immunol. 118:362-368.

13. Haslett, C., G. S. Worthen, P. C. Giclas, D. C. Morrison, J. E. Henson, and P. M. Henson. 1987. The pulmonary vascular sequestration of neutrophils in endotoxemia is initiated by an effect of endotoxin on the neutrophil. Am. Rev. Respir. Dis. 136:10-19.

14. Cohn, Z. A., and S. I. Morse. 1960. Functions and metabolic properties of poly-morphonuclear leukocytes II. The influence of a lipopolysaccharide endotoxin. J. Exp. Med. 111:689-704.

15. Tobias, P. S., K. Soldau, and R. J. Ulevitch. 1986. Isolation of a lipopolysaccharide-binding acute phase reactant from rabbit serum. J. Exp. Med. 164:777-793.

16. Schumann, R. R., S. R. Leong, G. W. Flaggs, P. W. Gray, S. D. Wright, J. C. Mathison, P. S. Tobias, and R. J. Ulevitch. 1990. Structure and function of lipopolysaccharide binding protein. Science (Wash. DC). 249:1429-1431.

17. McIntire, F. C., G. H. Barlow, H. W. Sievert, R. A. Finley, and A. L. Yoo. 1969. Studies on a lipopolysaccharide from $E$. coli: heterogeneity and mechanisms of reversible inactivation by sodium deoxycholate. Biochemistry. 8:40634066 .

18. Duncan, R. L., J. Hoffman, V. L. Tesch, and D. C. Morrison. 1986. Immunologic activity of lipopolysaccharides released from macrophages after the uptake of intact $E$. coli in vitro. J. Immunol. 136:2924-2929.

19. Westphal, O., and K. Jann. 1965. Bacterial lipopolysaccharides. Extraction with phenol-water and further applications of the procedure. In Carbohydrate Chemistry, Volume 5. R. C. Whistler, editor. Academic Press, Inc., New York, 83.

20. Ulevitch, R. J. 1978. The preparation and characterization of a radioiodinated bacterial lipopolysaccharide. Immunochemistry. 15:157-164.

21. Gimbrone, M. A., Jr., E. J. Shefton, and S. A. Cruise. 1978. Isolation and primary culture of endothelial cells. Tissue Culture Association Manual. 4:813817.

22. Tonnesen, M. G., D. C. Anderson, T. A. Springer, A. Knedler, N. Avdi, and P. M. Henson. 1989. Adherence of neutrophils to cultured human microvascular endothelial cells: stimulation by chemotactic peptides and lipid mediators, and dependence on the Mac-1, LFA-1, p150,95 glycoprotein family. J. Clin. Invest. 74:1581-1592.

23. Haslett, C., L. A. Guthrie, M. M. Kopaniak, R. B. Johnston, Jr., and P. M. Henson. 1985. Modulation of multiple neutrophil functions by preparative methods or trace concentrations of bacterial lipopolysaccharide. Am. J. Pathol. 119:101-110.

24. Young, S. K., G. S. Worthen, C. Haslett, M. G. Tonnesen, and P. M. Henson. 1990. Interaction between chemoattractants and bacterial lipopolysaccharide in the induction and enhancement of neutrophil adhesion. Am. J. Respir. Cell. Mol. Biol. 2:523-532.

25. Guthrie, L. A., L. C. McPhail, P. M. Henson, and R. B. Johnston Jr. 1984 The priming of neutrophils for enhanced release of oxygen metabolites by bacterial lipopolysaccharide: evidence for increased activity of the superoxide-producing enzyme. J. Exp. Med. 160:1656-1671.

26. Cham, B. E., and B. R. Knowles. 1976. A solvent system for delipidation of plasma or serum without protein precipitation. J. Lipid Res. 17:176-181.

27. Lowry, O. H., N. J. Rosenbrough, A. L. Fair, and R. S. Randall. 1951 Protein measurement with the Folin phenol reagent. J. Biol. Chem. 193:265275. 
28. Esko, J. D., and K. Y. Matsuoka. 1983. Biosynthesis of phosphatidylcholine from serum phospholipids in Chinese hamster ovary cells deprived of choline. J. Biol. Chem. 258:3051-3057.

29. Gabriel, K. F. 1978. A simple method of multiple comparisons of means. J. Am. Stat. Assoc. 73:724-729.

30. Levin, J., T. E. Poore, N. P. Zanber, and R. S. Oser. 1970. Detection of endotoxin in the blood of patients with sepsis due to gram-negative bacteria. $N$. Eng. J. Med. 283:1313-1316.

31. Rudbach, V. A., R. L. Anacker, W. T. Haskins, A. G. Johnson, K. C. Milner, and E. Ribi. 1966. Physical effects of reversible inactivation of endotoxin. Ann. N.Y. Acad. Sci. 33:629-143.

32. Ulevitch, R. J., A. R. Johnston, and D. B. Weinstein. 1981. New function for high-density lipoproteins. Isolation and characterizations of a bacterial lipopolysaccharide-high density lipoprotein complex formed in rabbit plasma. $J$. Clin. Invest. 67:827-837.

33. Ulevitch, R. J., and A. R. Johnston. 1978. The modifications of biophysical and endotoxic properties of bacterial lipopolysaccharide by serum. J. Clin. Invest. 62:1313-1324.

34. Koivuranta-vaara, P., D. Banda, and I. M. Goldstein. 1987. Bacterial-lipopolysaccharide-induced release of lactoferrin from human polymorphonuclear leukocytes: Role of monocyte-derived tumor necrosis factor. Infect. Immun. 55:2956-2961

35. Aida, Y., and M. J. Pabst. 1990. Priming of neutrophils by lipopolysaccharide for enhanced release of superoxide. Requirement for plasma but not for tumor necrosis factor-alpha. J. Immunol. 145:3017-3025.

36. Vosbeck, K., P. Tobias, H. Mueller, R. A. Allen, K. E. Arfors, R. J. Ulevitch, and L. A. Sklar. 1990. Priming of polymorphonuclear granulocytes by lipopolysaccharides and its complexes with lipopolysaccharide binding protein and high density lipoprotein. J. Leukocyte Biol. 47:97-104.
37. Wright, S. D., R. A. Ramos, P. S. Tobias, R. J. Ulevitch, and J. C. Mathison. 1990. CD14, a receptor for complexes of lipopolysaccharide (LPS) and LPS binding protein. Science (Wash. DC). 249:1431-1433.

38. Wright, S. D., R. A. Ramos, A. Hermanowski-Vosatka, P. Rockwell, and P. A. Detmers. 1991. Activation of the adhesive capacity of CR3 on neutrophils by endotoxin: dependence on lipopolysaccharide binding protein and CD14. $J$. Exp. Med. 173:1281-1286.

39. Galanos, C., E. Th. Rietschel, O. Luderitz, and O. Westphal. 1971. Interaction of lipopolysaccharide and lipid A with complement. Eur. J. Biochem. 19:143-152.

40. Stares, R. C., and F. S. Rosen. 1971. Host-dependent detoxification of bacterial endotoxins. In Microbial Toxins, Volume 5. S. J. Ajl, S. Kadis, and G Leinbaum, editors. Academic Press, Inc., New York. 151-164.

41. Galanos, C., and O. Luderitz. 1976. The role of the physical state of lipopolysaccharides in the interaction with complement:high molecular weight as a prerequisite for the expression of anticomplementary activity. Eur. J. Biochem. 65:403.

42. Wollenweber, H. W., and D. C. Morrison. 1985. Synthesis and biochemical characterization of a photoactivatable, iodinatable, cleavable bacterial lipopolysaccharide derivative. J. Biol. Chem. 260:15068-15074.

43. Tesh, V. L., S. W. Vukajlovich, and D. C. Morrison. 1988. Endotoxin interactions with serum proteins. Relationship to biologic activity. In Bacterial Endotoxins: Pathophysiological Effects, Clinical Significance, and Pharmacological Control. J. Levin, J. W. TenCate, A. Stusk, and H. R. Byller, editors. Alan R. Liss, Inc., New York. 47-52:47-62.

44. Anderson, D. C., L. J. Miller, F. G. Schmalstieg, R. Rothlein, and T. A. Springer. 1986. Contributions of the Mac-1 glycoprotein family to adherence-dependent granulocyte functions: structure function assessments employing subunit specific monoclonal antibodies. J. Immunol. 137:15-27. 